\title{
PROCESSING ZIRCONIA THROUGH ZIRCON SAND SMELTING WITH NaOH AS A FLUX
}

\author{
PEMBUATAN ZIRKONIA MELALUI METODE \\ PELEBURAN PASIR ZIRKON MENGGUNAKAN \\ NaOH SEBAGAI BAHAN IMBUH
}

\author{
YUHELDA, DESSY AMALIA and ENGGAN P. NUGRAHA \\ R\&D Centre for Mineral and Coal Technology \\ Jalan Jenderal Sudirman 623 Bandung 40211 \\ Phone (022) 6030483, Fax. (022) 6003373 \\ e-mail: yuhelda@tekmira.esdm.go.id
}

\begin{abstract}
Zirconia had been made through smelting the zircon sand along with $\mathrm{NaOH}$ as a flux. The zircon sand as the smelter feed was taken from CV. Kurnia Alam Sejati mine at Palangkaraya, Middle Kalimantan. Major content of the zircon sand was $28.04 \% \mathrm{ZrO}_{2}$ and $\mathrm{SiO}_{2} 51.22 \%$ with several minor oxides such as $0.54 \% \mathrm{HfO}_{2}, 2.53 \% \mathrm{Fe}_{2} \mathrm{O}_{3}, 10.53 \% \mathrm{TiO}_{2}, 3.27 \% \mathrm{Al}_{2} \mathrm{O}_{3}$ and less than $1 \%$ of alkali, alkaline earth and rare earth elements. In order to economizing the process, zircon sand upgrading was conducted prior to zirconia production. The upgrading process was conducted using several comprehensive equipments, consist of shaking table, magnetic separator and high tension separator (HTS). The upgraded sand contained $65.35 \%$ of $\mathrm{ZrO}_{2}+\mathrm{HfO}_{2}$ with $73.25 \%$ recovery, which was then used for smelting process at $650^{\circ} \mathrm{C}$ for 2 hours using $\mathrm{NaOH}$ as a flux. The product was then leached with water and sulphuric acid then crystallized to get precipitated zirconium hydroxide. The precipitated product was calcined at $900^{\circ} \mathrm{C}$ for 1 hour to get the zirconia and analyzed for its content. The zirconia content was $97.27 \%$ of $\mathrm{ZrO}_{2}+\mathrm{HfO}_{2}$ with $65.13 \%$ recovery.
\end{abstract}

Keywords: zirconia, zircon sand, smelting, upgrading process and concentrate

\begin{abstract}
ABSTRAK
Pembuatan zirkonia telah dilakukan dengan melebur pasir zirkon menggunakan $\mathrm{NaOH}$ sebagai bahan imbuh. Pasir zirkon yang digunakan sebagai bahan baku zirkonia berasal dari lokasi penambangan pasir zirkon CV. Kurnia Alam Sejati di Palangkaraya, Kalimantan Tengah, dengan kandungan $\mathrm{ZrO}_{2}$ sebesar 28,04\% dan silikat $\left(\mathrm{SiO}_{2}\right)$ 51,22\%, serta pengotor-pengotor lainnya berupa $\mathrm{HfO}_{2}$ sebasar $0,54 \%, \mathrm{Fe}_{2} \mathrm{O}_{3}$ sebesar 2,53\%, $\mathrm{TiO}_{2} \mathrm{10}, 53 \%, \mathrm{Al}_{2} \mathrm{O}_{3} 3,27 \%$, sedangkan pengotor alkali, alkali tanah dan logam tanah jarangnya $<1 \%$. Pasir zirkon tersebut belum ekonomis untuk menjadi bahan baku pembuatan zirkonia, maka perlu dilakukan peningkatan kadar terlebih dahulu. Proses peningkatan kadar dilakukan menggunakan serangkaian peralatan yang terdiri atas shaking table, magnetic separator dan HTS. Hasil proses peningkatan diperoleh konsentrat berkadar $65.35 \%\left(\mathrm{ZrO}_{2}+\mathrm{HfO}_{2}\right)$ dengan perolehan sebesar 73,25\%. Konsentrat yang diperoleh kemudian digunakan untuk pembuatan zirkonia. Konsentrat tersebut dicampur dengan $\mathrm{NaOH}$ sebagai bahan imbuh, lalu dilebur pada suhu $650^{\circ} \mathrm{C}$ selama 2 jam. Hasil peleburan selanjutnya dilarutkan dengan air dan asam sulfat. Larutan kaya yang diperoleh dikristalisasi dan dikalsinasi pada suhu $900^{\circ} \mathrm{C}$ selama 1 (satu) jam untuk mendapatkan zirkonia. Hasil diperoleh adalah zirkonia berkadar 97,27\% $\left(\mathrm{ZrO}_{2}+\mathrm{HfO}_{2}\right)$ dengan perolehan sebesar $65,13 \%$.
\end{abstract}

Kata kunci: zirkonia, pasir zirkon, peleburan, peningkatan kadar dan konsentrat 


\section{INTRODUCTION}

Zirconia $\left(\mathrm{ZrO}_{2}\right)$ known as baddeleyite is hardly found in nature. Such a material can be processed from zircon sand $\left(\mathrm{ZrSiO}_{4}\right)$. Zirconia has three crystal structures, namely monoclinic, tetragonal and cubic. Both monoclinic and tetragonal zirconia are unstable at $1000-1100^{\circ} \mathrm{C}$ due to reversible transformation occurrence at such temperatures and results in volume change of the material. Of the three-zirconia type, cubic zirconia $\left(\mathrm{k}-\mathrm{ZrO}_{2}\right)$ is the stable one at those temperature. Generally, zirconia has high melting point $\left(2700^{\circ} \mathrm{C}\right)$, low thermal conductivity and can be formed into stable phase by adding bivalent or trivalent oxides, such as $\mathrm{CaO}$, $\mathrm{MgO}$ and $\mathrm{Y}_{2} \mathrm{O}_{3}$ (Anonim, 2009; Bobbin, 2008; Anonim, 2010). Based on such properties, zirconia can be applied for optical, fiber and color tv glasses as well as advanced ceramic to be applied in machine/motor component, chemical pump, nozzle, cylinder lining, piston head, valve and fuel cell system and also for controlling fuel and oxygent within the machine. By controlling both fuel and oxygent makes best efficiency on vehicle machine and reduces environment impact (Anonim, 2006 and http://www.zirox.co.in/advanced materials di vision.htm accessed on 15 September 2009 at 13.44).

Making the zirconia can be made through smelting zircon sand and alkali compound as a flux. The use of alkali compound in this process is named as alkali fusion. The very reactive alkali compound to be applied is $\mathrm{NaOH}$. The purpose of zircon sand smelting is to break chemical bond between $\mathrm{ZrO}_{2}$ and $\mathrm{SiO}_{2}$ to form alkali zirconium compound $\left(\mathrm{Na}_{2} \mathrm{ZrO}_{3}\right)$ and sodium silicate $\left(\mathrm{Na}_{2} \mathrm{SiO}_{3}\right)$ at $650^{\circ} \mathrm{C}$ (Kwela, 2006; Yuhelda et al., 2010). In order to separate quartz, the smelted product should be leached in water and the residue from water leaching was used for further leaching with sulphuric acid to have zirconium sulphate (Rehim, 2005; http://www.alkane.com.au/pdf/asx/archive/20 080408.pdf). The zirconia was produced by crystallizing zirconium sulphate and calcining the crystal.

Raw material for alkali fusion process is the zircon sand more than $65 \%$ of $\mathrm{ZrO}_{2}+\mathrm{HfO}_{2}$ in order to economizing the process. However, the natural zircon sand content is only 1-5\% of $\mathrm{ZrO}_{2}$, therefore upgrading process is required. The zircon sand upgrading process has been conducted to separate gangue mineral such as quartz, ilmenite, rutile, xenotim, monazite and others (Saleh and Pramusanto, 2007; Yuhelda et al., 2009).

The objective of this study is to utilize zircon sand for zirconia production. This can increase the added value of the sand. Referring to the export price of upgraded zircon (Rp 14,500/kg) and the price of zircon (Rp. 891,800/kg), such zircon processing is reasonable for increasing the local and national government income.

\section{METHODOLOGY}

The zircon sand for zirconia production was characterized in order to evaluate chemical composition, particle size distribution and mineralogy character. Mineral composition was detected by X-ray diffraction instrument and chemical composition was analyzed by XRF instrument. Particle size distribution of sand was conducted by setting several sieves from 60,100, 150 and 200 meshes and then, generated on ro-tap sieve shaker for 1 hour. The retained and passing materials was measured for its weight.

The zircon sand was then upgraded to separate its mineral association such as quartz, ilmenite, rutile, hematite, magnetite, pyrite, limonite, xenotime and monazite. Upgrading process was accomplished through physical separation process based on densities, magnetism properties and conductivity. The upgrading process was completed using shaking table, magnetic separator and high tension separator (HTS).

Separation of mineral employed shaking table and water stratification media with the flowrate of 12 liters/minute, $3^{\circ}$ inclination of the table and $6 \mathrm{~mm}$ stroke (Yuhelda et al., 2012; Saleh and Pramusanto, 2007). The product consisted of $\mathrm{ZrO}_{2}+\mathrm{HfO}_{2}$ as a concentrate and quartz, clay, xenotime, monazite, magnetite, hematite, rutile and ilmenite as tailing products. A few of concentrates were characterized by XRF instrument for analyzing its contents. The rest concentrates were then upgraded using magnetic separator. Some minerals such as magnetite, hematite, limonite, ilmenite and pyrite were separated by magnetic intensity of 10,000-20,000 gauss (Yuhelda et al., 
2012). The non-magnetic product was then characterized by XRF method and then separated using HTS. Before separation, the material had to be dried first one night at $100^{\circ} \mathrm{C}$. The feeder speed was set at 25.06 rpm and $100^{\circ} \mathrm{C}$ while the roll speed at 240 rpm. The HTS product was also examined through XRF analysis.

Further separation with silicate had been accomplished with smelting. The smelting was intended to break the strong bond between $\mathrm{ZrO}_{2}$ and $\mathrm{SiO}_{2}$ which can be completed around $2700^{\circ} \mathrm{C}$ without any flux addition. Interms of acquiring lower temperature for the process, it is required to add $\mathrm{NaOH}$ as a flux (Kwela, 2006). Upgraded zircon sand smelting was prepared within a crucible furnace. In order to get $\mathrm{ZrO}_{2}+\mathrm{HfO}_{2}$ more than $65 \%$, the upgraded sand was mixed with $\mathrm{NaOH}$ as a flux for some stoichiometric amounts then stirred and smelted at $650^{\circ} \mathrm{C}$ (Yuhelda et al., 2010). The smelted product was then cooled, ground and prepared for silica dissolution. The product was also examined by XRD instrument to identify the $\mathrm{Na}_{2} \mathrm{ZrO}_{3}$ and $\mathrm{Na}_{2} \mathrm{SiO}_{3}$.

Silica dissolution was generated in water to have zirconium and then leached in 6-M sulphuric acid to produce zirconium sulfate (Yuhelda et al., 2012; Rehim, 2005). The solution was then precipitated by adding aqueous ammonia until white precipitation appeared as zirconium hydroxide. Then it was calcined at $900^{\circ} \mathrm{C}$ for 1 hour (Kwela, 2006; Yuhelda et al., 2010). The whole process can be seen in Figure 1.

\section{RESULTS AND DISCUSSION}

The zirconia production consists of four steps; namely raw material characterization, upgrading process, smelting process and zirconia making. Chemical composition of zircon sand is presented in Table 1. Zircon sand contains 28.04\% $\mathrm{ZrO}_{2}$ and $51.22 \%$ $\mathrm{SiO}_{2}$. As known that pure zircon contains $33.48 \% \mathrm{SiO}_{2}$, therefore some treatment must be completed to fulfill required specification of smelting process namely more than $65 \%$ of $\mathrm{ZrO}_{2}+\mathrm{HfO}_{2}$. The zircon sand also consists of rare earth elements and radioactive materials that are less than $1 \%$. The amounts of those elements are not hazardous. It is not necessary to have special treatment for those material separation. According to National Nuclear Energy Agency of Indonesia, secure limitation for radioactive in materials is $\mathbf{5 0 0}$ ppm.

Other characterization is particle size distribution. The size was set to 60, 100, 150 and 200 meshes. The distributions were stated in weight percent. The data was used for calculating each oxide content at each particle size as seen in Table 2. The calculation showed that zircon oxide $\left(\mathrm{ZrO}_{2}\right)$ is well distributed at +100 mesh for $88.94 \%$ and the calculation grade is $28.27 \%$. The $\mathrm{ZrO}_{2}$ is not well distributed at -200 mesh. While, quartz $\left(\mathrm{SiO}_{2}\right)$ is well distributed in any sizes within almost similar grade, the largest amount can be found at $-100+150$ mesh. Nevertheless, the gangue minerals such as $\mathrm{TiO}_{2}, \mathrm{Fe}_{2} \mathrm{O}_{3}, \mathrm{Al}_{2} \mathrm{O}_{3}$, alkali mineral, alkali, rare earth, rare elements also occur in small number $(<1 \%)$. The calculation result is similar with chemical composition in Table 1. Therefore, chemicals amounts calculation wasdone by using chemical composition analysis result (28.24\% of $\left.\mathrm{ZrO}_{2}\right)$. Those particle size distributions can be used for determining liberation degree of raw material. At coarse size, the liberation is quite good and gain highest liberation at 200 mesh as seen in Table 3, but the liberation has not reached $100 \%$ yet. It is because of gangue minerals especially rutile that attached on zirconsilicate, which can be seen in Figure 2.

The conviction of mineral content in the raw material was analyzed by XRD method. Referring to Figure 3, zircon silicate appeared as the major mineral followed by quartz, microcline and ilmenite. The last three minerals were in small intensity as they were present in small amounts that supported by chemical composition as shown in Table 1. 


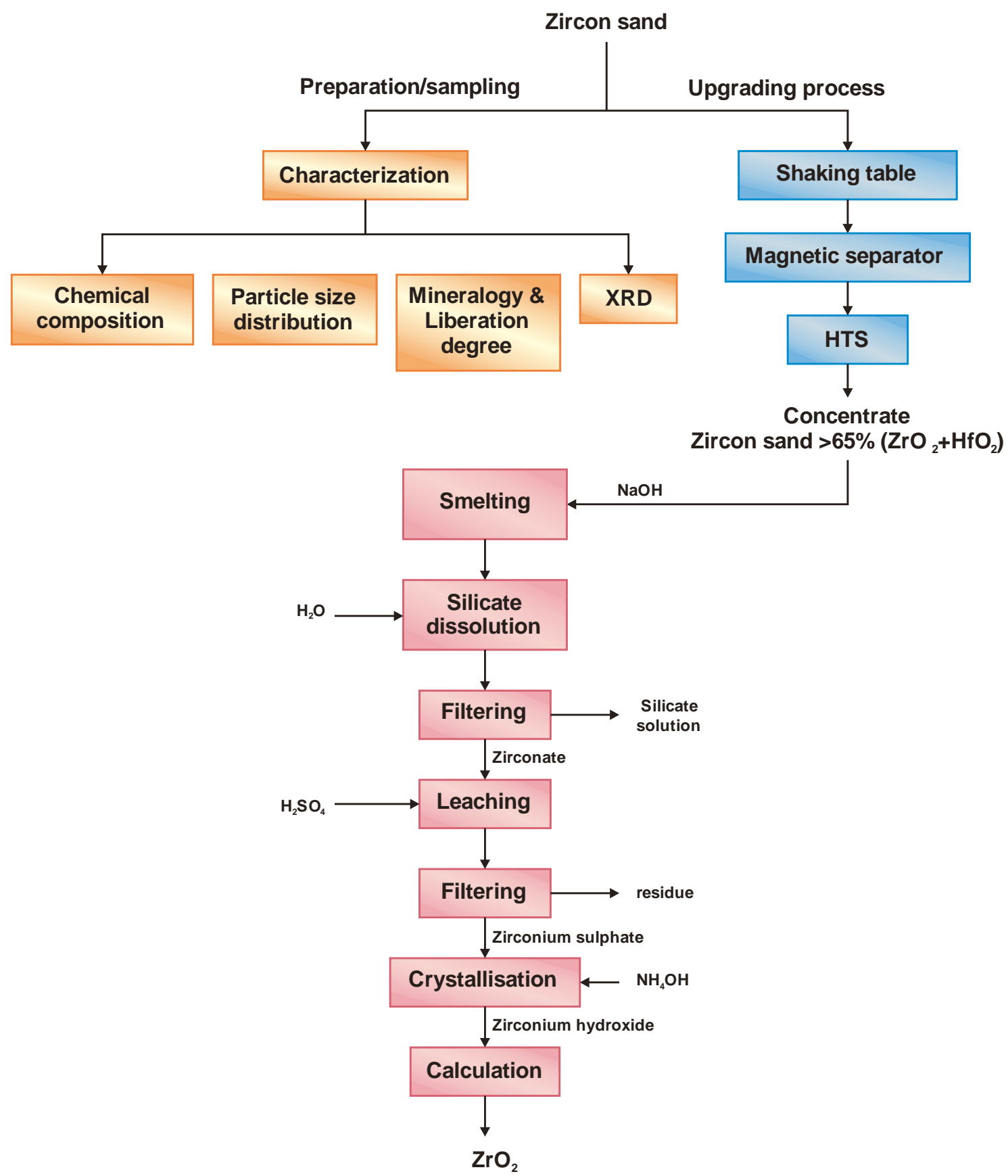

Figure 1. A flow chart showing the activities of zirconia making

Previous characterization showed that the upgrading process for zircon sand had to be completed before smelting process. Continuous physical treatment based on three different properties namely densities, magnetic strength and conductivity had been done. The result of all upgrading process can be seen in Table 4. Using HTS, the $\mathrm{ZrO}_{2}$ increased from 28.04 to $64.01 \%$ $\mathrm{ZrO}_{2}$ or $65.35 \%\left(\mathrm{ZrO}_{2}+\mathrm{HfO}_{2}\right)$ with recovery of $73.25 \%$. It means that separation process of quartz and ilmenite from zircon sand run well and make the $\mathrm{ZrO}_{2}$ content increase in final concentrate. 
Table 1. Chemical composition of zircon sand

\begin{tabular}{clcccc}
\hline No. & Oxides & Amount (\%) & No. & Oxides & Amount (\%) \\
\hline 1 & $\mathrm{ZrO}_{2}$ & 28.04 & 17 & $\mathrm{CeO}_{2}$ & 0.020 \\
2 & $\mathrm{SiO}_{2}$ & 51.22 & 18 & $\mathrm{CO}_{2} \mathrm{O}_{3}$ & 0.019 \\
3 & $\mathrm{TiO}_{2}$ & 10.53 & 19 & $\mathrm{Cr}_{2} \mathrm{O}_{3}$ & 1.180 \\
4 & $\mathrm{Al}_{2} \mathrm{O}_{3}$ & 3.27 & 20 & $\mathrm{Dy}_{2} \mathrm{O} 3$ & 0.001 \\
5 & $\mathrm{Fe}_{2} \mathrm{O}_{3}$ & 2.53 & 21 & $\mathrm{Y}_{2} \mathrm{O}_{3}$ & 0.051 \\
6 & $\mathrm{MnO}$ & 0.063 & 22 & $\mathrm{Gd}_{2} \mathrm{O}_{3}$ & 0.007 \\
7 & $\mathrm{CaO}$ & 0.35 & 23 & $\mathrm{ThO}_{2}$ & 0.013 \\
8 & $\mathrm{MgO}$ & 0.0452 & 24 & $\mathrm{U}_{3} \mathrm{O}_{3}$ & 0.012 \\
9 & $\mathrm{CuO}$ & 0.045 & 25 & $\mathrm{La}_{2} \mathrm{O}_{3}$ & $<0.001$ \\
10 & $\mathrm{~K} 2 \mathrm{O}$ & 0.012 & 26 & $\mathrm{Lu}_{2} \mathrm{O}_{3}$ & 0.001 \\
11 & $\mathrm{P} 2 \mathrm{O}$ & 0.022 & 27 & $\mathrm{Nd}_{2} \mathrm{O}_{3}$ & 0.11 \\
12 & $\mathrm{SO}$ & 0.11 & 28 & $\mathrm{Pr}_{6} \mathrm{O}_{11}$ & 0.0114 \\
13 & $\mathrm{ZnO}$ & 0.064 & 29 & $\mathrm{Sm}_{2} \mathrm{O}_{3}$ & 0.007 \\
14 & $\mathrm{NiO}$ & 0.010 & 30 & $\mathrm{Yb}_{2} \mathrm{O}_{3}$ & 0.256 \\
15 & $\mathrm{PbO}$ & 0.019 & 31 & $\mathrm{SnO}_{2}$ & 0.81 \\
16 & $\mathrm{HfO}$ & 32 & $\mathrm{LOI}_{2}$ & 0.41 \\
\hline
\end{tabular}

Table 2. Particle size distribution of zircon sand part 1

\begin{tabular}{|c|c|c|c|c|c|c|c|c|c|c|c|c|}
\hline \multirow{2}{*}{$\begin{array}{l}\text { Sizes } \\
\text { (mesh) }\end{array}$} & \multirow{2}{*}{$\begin{array}{l}\text { Weight } \\
\text { (grams) }\end{array}$} & \multirow{2}{*}{$\begin{array}{c}\% \\
\text { Weight }\end{array}$} & \multicolumn{10}{|c|}{ Content (\%) } \\
\hline & & & $\mathrm{ZrO}_{2}$ & $\mathrm{SiO}_{2}$ & $\mathrm{TiO}_{2}$ & $\mathrm{Al}_{2} \mathrm{O}_{3}$ & $\mathrm{Fe}_{2} \mathrm{O}_{3}$ & $\mathrm{MnO}$ & $\mathrm{CaO}$ & $\mathrm{MgO}$ & $\mathrm{SO}_{3}$ & $\mathrm{~K}_{2} \mathrm{O}$ \\
\hline+60 & 3 & 51.4 & 30.05 & 51.07 & 8.77 & 4.33 & 2 & 0.065 & 0.083 & 0.39 & 0.088 & 0.012 \\
\hline$-60+100$ & 9.66 & 37.4830 & 28.27 & 54.61 & 9.96 & 1.08 & 2.1 & 0,051 & 0.12 & 0.34 & 0.088 & 0.009 \\
\hline$-100+150$ & 121.29 & 6.0645 & 28.32 & 40.89 & 18.42 & 1.11 & 2.64 & 0,055 & 0.17 & 0.34 & 0.10 & 0.010 \\
\hline$-150+200$ & 87.15 & 4.3575 & 34.66 & 31.23 & 17.32 & 0.86 & 3.92 & 0,100 & 0.25 & 0.24 & 0.24 & 0.009 \\
\hline-200 & 2.30 & 0.6150 & 46.18 & 31.30 & 5.92 & 0.55 & 4.23 & 0,074 & 0.17 & 0.13 & 0.66 & 0.027 \\
\hline $\begin{array}{l}\text { Calculation } \\
\text { grade }(\%)\end{array}$ & 99.63 & 99.9815 & 29.29 & 50.59 & 0.12 & 2.10 & 2 & 0 & 0.19 & 0.36 & 0.095 & 0.010 \\
\hline
\end{tabular}

Table 2. Particle size distribution of zircon sand part 2 (continued)

\begin{tabular}{cccccccccccccc}
\hline \multirow{2}{*}{$\begin{array}{c}\text { Sizes } \\
\text { (mesh) }\end{array}$} & \multicolumn{10}{c}{ Content (\%) } \\
\cline { 2 - 12 } & $\mathrm{P}_{2} \mathrm{O}_{5}$ & $\mathrm{HfO}_{2}$ & $\mathrm{CeO}_{2}$ & $\mathrm{CO}_{2} \mathrm{O}_{3}$ & $\mathrm{SnO}_{2}$ & $\mathrm{Y}_{2} \mathrm{O}_{3}$ & $\mathrm{ThO}_{2}$ & $\mathrm{U}_{3} \mathrm{O}_{8}$ & $\mathrm{La}_{2} \mathrm{O}_{3}$ & $\mathrm{ZnO}$ & $\mathrm{Cr}_{2} \mathrm{O}_{3}$ & $\mathrm{LOI}$ \\
\hline+60 & $\mathrm{O}$ & 0.59 & $<0.001$ & 0.017 & $<0.001$ & 0.051 & 0.011 & 0.011 & $<0.001$ & 0.064 & 1.18 & 0.39 \\
$-60+100$ & 0.19 & 0.73 & $<0.001$ & 0.019 & 0.40 & 0.052 & 0.012 & 0.012 & $<0.001$ & 0.023 & 1.31 & 0.36 \\
$-100+150$ & 0.21 & 0.72 & $<0.001$ & 1.67 & 4.63 & 0.046 & 0.016 & 0.015 & $<0.001$ & 0.033 & 1.67 & 0.38 \\
$-150+200$ & 0.26 & 0.89 & $<0.001$ & 1.00 & 8.38 & 0.056 & $<0.001$ & $<0.001$ & $<0.001$ & 0.033 & 1.00 & 0.37 \\
-200 & 0.27 & 1.02 & $<0.001$ & 0.66 & 6.73 & 0.090 & $<0.001$ & $<0.001$ & $<0.001$ & 0.150 & 0.66 & 1.04 \\
+60 & 0.16 & 0.59 & $<0.001$ & 0.017 & $<0.001$ & 0.051 & 0.011 & 0.011 & $<0.001$ & 0.064 & 1.18 & 0.39 \\
\hline $\begin{array}{c}\text { Calculation } \\
\text { grade (\%) }\end{array}$ & 0.40 & 0.66 & $<0.001$ & 0.16 & 0.80 & 0.051 & 0.011 & 0.011 & 0.001 & 0.045 & 1.24 & 0.375 \\
\hline
\end{tabular}


Table 3. Liberation degree of zircon sand

\begin{tabular}{cc}
\hline $\begin{array}{c}\text { Particle size } \\
(\text { mesh })\end{array}$ & $\begin{array}{c}\text { Liberation degree } \\
(\%)\end{array}$ \\
\hline+60 & 82.66 \\
$-60+100$ & 84.39 \\
$-100+150$ & 86.42 \\
$-150+200$ & 88.47 \\
-200 & 91.16 \\
\hline
\end{tabular}

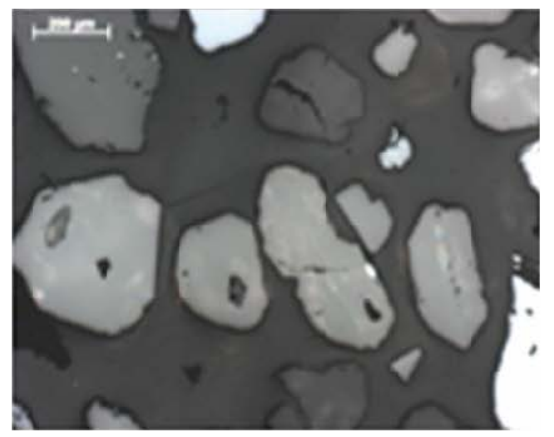

(a)

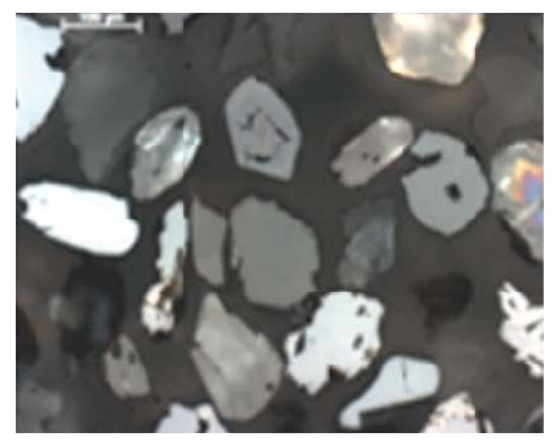

(c)
Shaking table method employed density differences of zircon, quartz, ilmenite and rutile. Zircon sand has highest density (4.6$5.8 \mathrm{~g} / \mathrm{cm}^{3}$ ) among them (Harben, 1995), therefore quartz and ilmenite were separated and went to tailing (Yuhelda, et al., 2008). Process using water flow velocity with velocity of 12 litre/minute for zircon sand (Yuhelda, et al., 2008; Saleh and Pramusanto, 2007) resulted $45.18 \%$ of $\mathrm{ZrO}_{2}+\mathrm{HfO}_{2}$ content in the concentrate. If the velocity of was too fast, it caused the raw material went to middling or tailing product.

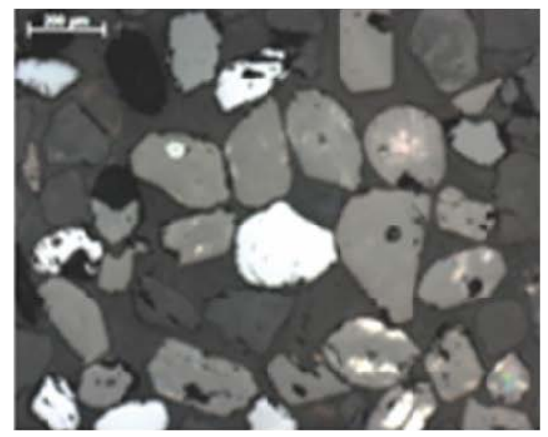

(b)

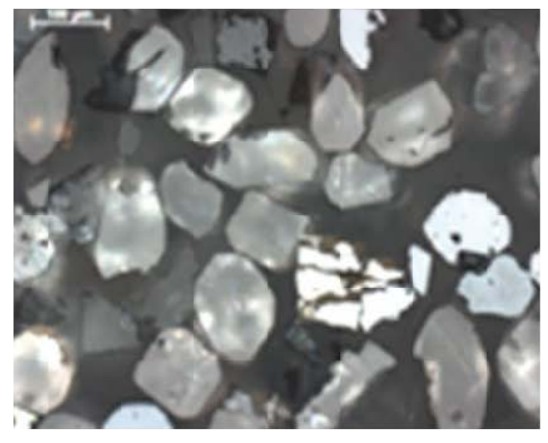

(d)

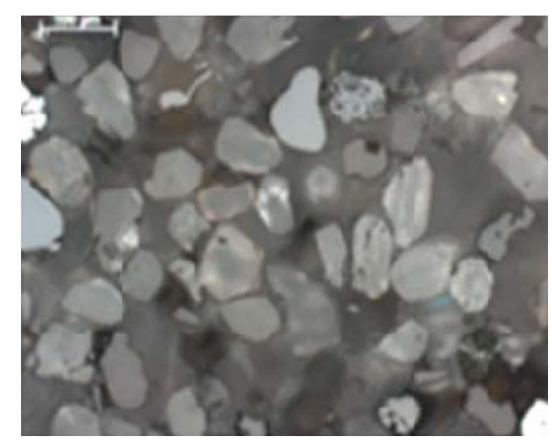

(e)

Figure 2. Photomicrograph of zircon sand polished section (a) +60 mesh, (b) -60+100 mesh, (c) -100+150 mesh, -150+200 mesh dan -200 mesh 

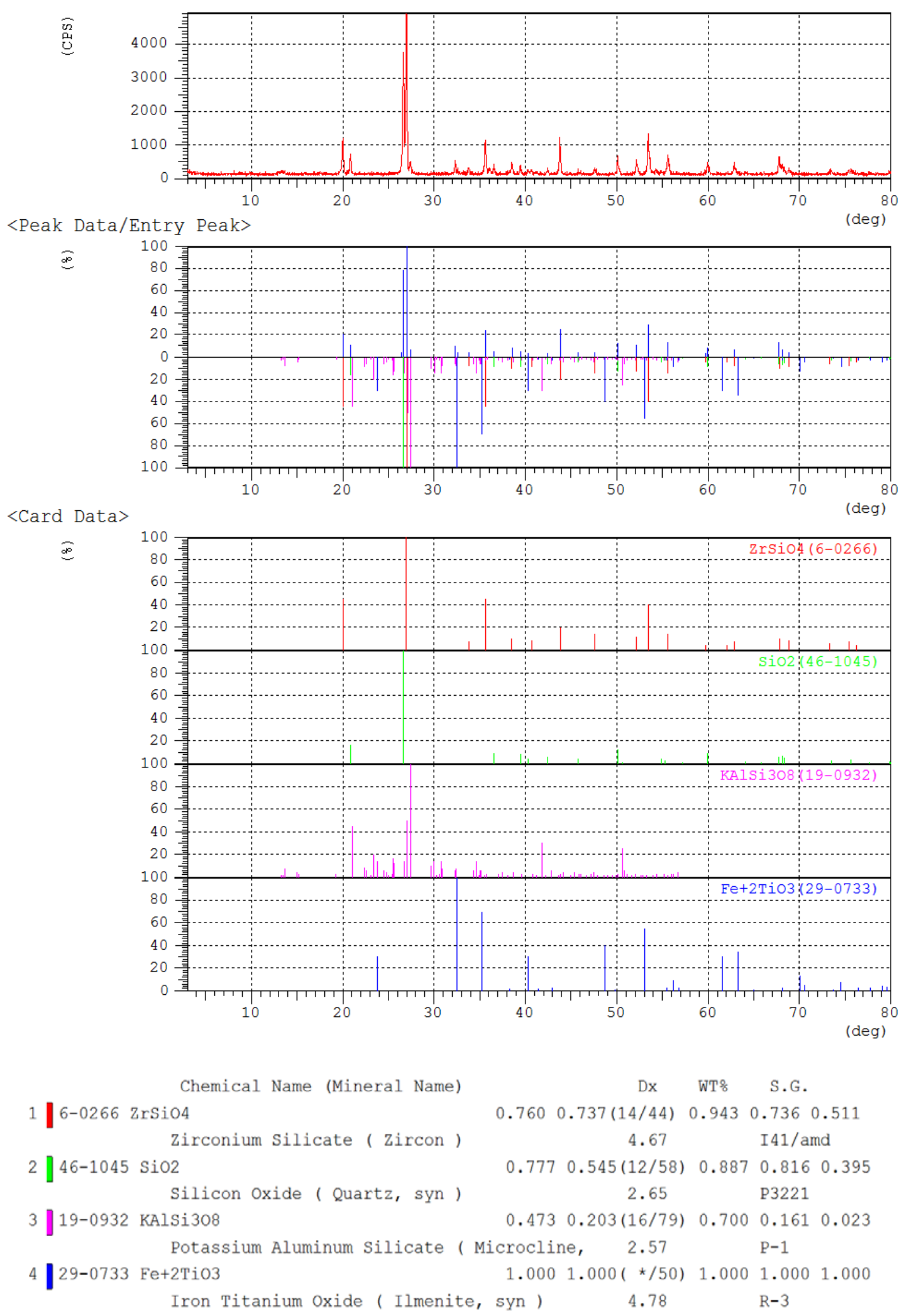

Figure 3. Result of X-Ray diffraction result for zircon sand 
Table 4. Result of zircon sand upgrading process

\begin{tabular}{|c|c|c|c|c|c|c|c|c|c|c|}
\hline \multirow{2}{*}{ Equipment } & \multirow{2}{*}{$\begin{array}{c}\text { Sample } \\
\text { Weight } \\
(\mathrm{kg})\end{array}$} & \multirow{2}{*}{$\begin{array}{c}\text { Concentrate } \\
\text { Weight } \\
\text { (Kg) }\end{array}$} & \multirow{2}{*}{$\begin{array}{c}\text { Recovery } \\
(\%)\end{array}$} & \multicolumn{7}{|c|}{ Content (\%) } \\
\hline & & & & $\mathrm{ZrO}_{2}$ & $\mathrm{SiO}_{2}$ & $\mathrm{Fe}_{2} \mathrm{O}_{3}$ & $\mathrm{TiO}_{2}$ & $\mathrm{Al}_{2} \mathrm{O}_{3}$ & $\mathrm{HfO}_{2}$ & LOI \\
\hline Shaking table & 102.170 & 58.760 & 57.51 & 44.21 & 49.59 & 2.12 & 1.89 & 0.75 & 0.97 & 0.06 \\
\hline $\begin{array}{l}\text { Magnetic } \\
\text { separation }\end{array}$ & 56.280 & 47.838 & 85.00 & 61.72 & 33.62 & 1.09 & 0.89 & 0.80 & 2.18 & 0,01 \\
\hline $\begin{array}{l}\text { High Tension } \\
\text { separation }\end{array}$ & 55.00 & 41.39 & 73.25 & 64.01 & 32.22 & 0.11 & 1.15 & 0.05 & 1.34 & 0.07 \\
\hline
\end{tabular}

Concentrate from stratification process served as the feed for magnetic separation process using magnetic intensity of 12.000 gauss. The result shows that the iron content decreases from 2.12 to $1.09 \%$ and increased the zircon content from $44.21 \%$ to $61.72 \%$ with $85 \%$ recovery in the concentrate because of ilmenite and mangnetic minerals have been separated at the process (Yuhelda, et al, 2009). Then the upgrading process was continued with conductivitybased property. Zircon as a conductive material was separated from non conductive one such as rutile. The product contained $65.35 \%$ of $\mathrm{ZrO}_{2}+\mathrm{HfO}_{2}$ that was ready for smelting process. The smelting process was held at $650^{\circ} \mathrm{C}$ for 2 hours using upgraded zircon sand as the feed. Such material was mixed with $\mathrm{NaOH}$ as a flux. Smelted product was then analyzed through XRD and the result can be seen in Figure 4. It is showed that smelted product consisted of two major minerals namely sodium zirconate and sodium silicate. It is indicated that smelting process had broken off the chemical bond of zircon silicate as reported by Kwela (2006). The sodium zirconate intensity was stronger than that of sodium silicate because of $\mathrm{SiO}_{2}$ content was smaller than $\mathrm{ZrO}_{2}$ content. The reaction of smelting process is as follows:

$\mathrm{ZrSiO}_{4}+4 \mathrm{NaOH} \stackrel{650^{\circ} \mathrm{C}}{\longrightarrow} \mathrm{Na}_{2} \mathrm{ZrO}_{3}+\mathrm{Na}_{2} \mathrm{SiO}_{3}+$ $2 \mathrm{H}_{2} \mathrm{O}$
Separating sodium zirconate and sodium silicate was performed through disolving the silicates in water. The residue was then leached with 6-M sulphuric acid to produce zirconium sulphate solution. The solution was then added with aqueous ammonia to precipitate zirconium hidroxide and continued to be calcined at $900^{\circ} \mathrm{C}$ for 1 hour. The produced zirconia from calcination was examined its chemical composition. The result can be seen in Table 5 .

Table 5. Zirconia composition

\begin{tabular}{cc}
\hline Oxides & Content (\%) \\
\hline $\mathrm{ZrO}_{2}$ & 95.67 \\
$\mathrm{HfO}_{2}$ & 1.60 \\
$\mathrm{SiO}_{2}$ & 1.04 \\
$\mathrm{Fe}_{2} \mathrm{O}_{3}$ & 0.15 \\
$\mathrm{Al}_{2} \mathrm{O}_{3}$ & 0.11 \\
$\mathrm{TiO}_{2}$ & 0.90 \\
\hline
\end{tabular}

The produced zirconia had high purity (95.67\%) with $65.35 \%$ recovery and major gangue $\mathrm{SiO}_{2}(1.04 \%)$ which is free silica that can not dissolve in hot water $\left(90^{\circ} \mathrm{C}\right)$. Meanwhile, others gangue such as $\mathrm{Fe}_{2} \mathrm{O}_{3}$, $\mathrm{Al}_{2} \mathrm{O}_{3}$ dan $\mathrm{TiO}_{2}$ content are less than $1 \%$ each, therefore, they were not detected in $X R D$ result as seen in Figure 4. Strong intensity of $\mathrm{ZrO}_{2}$ can be seen at the peaks of diagram (Figure 5). 

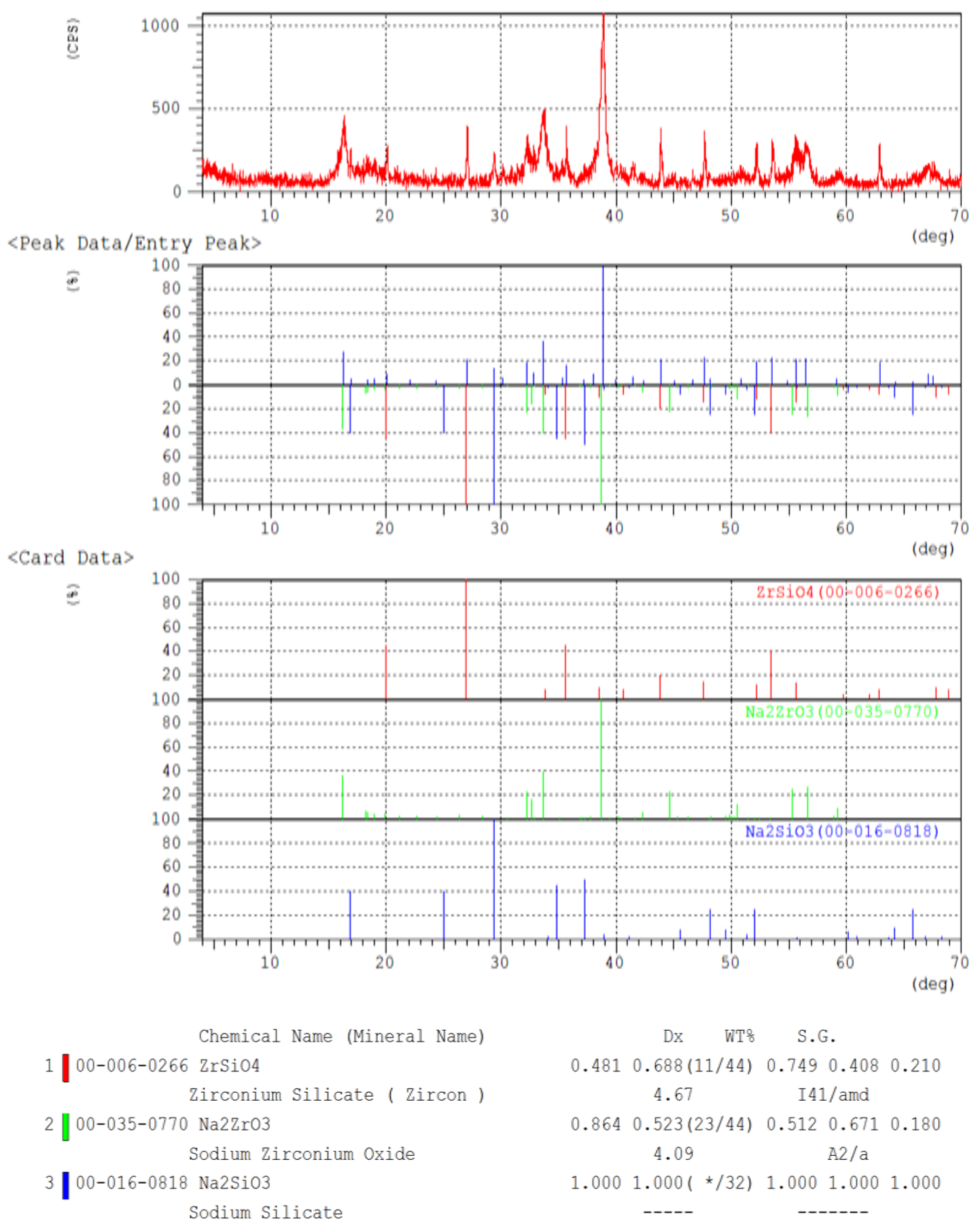

Figure 4. Result of x-ray diffraction on smelted zircon sand 


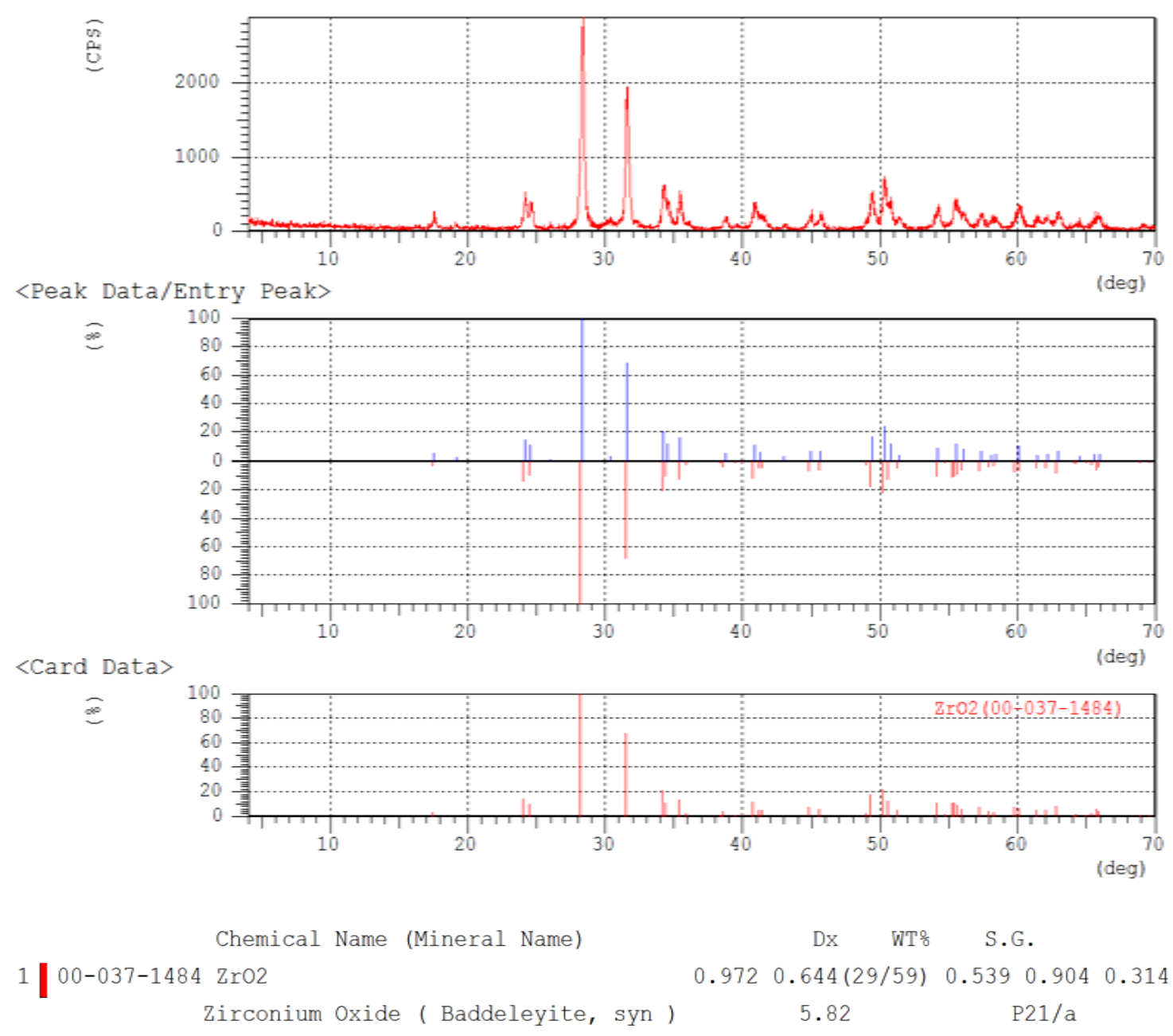

Figure 5. X-ray diffraction of the product

\section{CONCLUSION}

Palangkaraya zircon sands consisted of $28.04 \% \mathrm{ZrO}_{2}$. It is well distributed within a +100 mesh for $88.94 \%$ with liberation of 84.39\%. Upgraded zircon sand resulted from simultaneous concentration equipment increased $\mathrm{ZrO}_{2}$ content from 28.4 to $64.01 \%$ as $\mathrm{ZrO}_{2}+\mathrm{HfO}_{2}$ with $73.25 \%$ recovery, and reduce the gangue minerals such as $\mathrm{SiO}_{2}$ and others.

The addition of $\mathrm{NaOH}$ in smelting process has proved to be effective in breaking the strong bond between $\mathrm{ZrO}_{2}$ and $\mathrm{SiO}_{2}$ of zircon sand at $650^{\circ} \mathrm{C}$. The smelted zircon sand identified by XRD showed sodium zirconate and sodium silicate. Further process of sodium zirconate succeedly result zirconia. The zirconia contained $\mathrm{ZrO}_{2}$ $95.67 \% \quad \mathrm{ZrO}_{2}$ and $1,60 \% \quad \mathrm{HfO}_{2}$, or $\left(\mathrm{ZrO}_{2}+\mathrm{HfO}_{2}\right) 97.27 \%$ with $65.13 \%$ recovery.

\section{ACKNOWLEDGEMENTS}

The authors wish to thank the Ministry of Energy and Mineral Resources for funding the research. The authors alos would like to show appreciation to Ir. Tatang Wahyudi, M.Sc for his valuable insight and crticism, which improved the quality of this manuscript and all colleagues who lent their expertise and technical support to this project.

\section{REFERENCES}

Anonim, 2006. Aplications and preparations of zirconia and stabilized zirconia powders.

http://www.standfordmaterials.com accessed on 31 May 2006 at 15.40 
http://www.zirox.co.in/advanced materials divisi on.htm, browsed on 15 September 2009 at 13.44.

Anonim, 2010. Zinc and Zirconia. Booklet of learning Material warkshop, The Royal Society of Chemistry, London

Anonim, 2008. Demonstration Pilot Plant Commissioning Brings World Class Dubbo Zirconia Project closer. ASX Announcement, 6 pages. http://www.alkane.com.au/pdf/asx/archi ve/20080408.pdf.

Bobbin, 2008. Komputasi numerik untuk analisis karakteristik keramik psz dengan aditif Cao, mgo berbasis matlab. Tesis, Pasca Sarjana Universitas Sumatra Utara, Medan.

Kwela, Z., 2006. Alkali-fusion processes for the recovery of zirconia and zirconium chemical from zircon sand. Dissertation. Faculty of Engineering Built Environment and Information Technology, University of Pretoria,147 p.

Harben, P.W., 1995. The Indutrial Minerals Handy Book, 2nd edition, Industrial Minerals Devision, Metal Bulletin PLC, London, United Kingdom.
Rehim, A. M., 2005. A new technique for extracting zirconium from egiptian zircon concentrate. International Journal of Mineral Processing, 76, $\mathrm{p}$. 234-243.

Saleh, N. and Pramusanto, 2007. Heavy Mineral Sands Separation of Waringin, Central, Kalimantan. Prosiding Kolokium Pertambangan, p. 147-156.

Yuhelda, Pramusanto, Saleh, N.; Wahyudi, A., Rodliyah, I., Setyatmoko, E., Somantri, 2008. Pembuatan zirconia dari pasir zirkon. Laporan Penelitian. Puslitbang Teknologi Mineral dan Batubara, Bandung.

Yuhelda, Pramusanto, Saleh N., Setyatmoko E., Somantri, 2009. Pembuatan zirconia semi stabil. Laporan Penelitian. Puslibang Teknologi Mineral dan Batubara, Bandung.

Yuhelda, Pramusanto, Saleh N., Amalia D., Setyatmoko E. Somantri, 2010. Pembuatan zirconia stabil. Laporan Penelitian. Puslitbang Teknologi Mineral dan Batubara, Bandung.

Yuhelda, Pramusanto, Saleh $\mathrm{N}$ and Amalia D, 2012. Optimalisasin Pelarutan Natrium zirkonat secara kontiniu. Laporan Penelitian. Puslibang Teknologi Mineral dan Batubara, Bandung. 